\title{
Substrate-dependent bacterivory by intertidal benthic copepods
}

\author{
Clio Cnudde $\cdot$ Tom Moens $\cdot$ Anne Willems • \\ Marleen De Troch
}

Received: 17 July 2012/Accepted: 5 October 2012

(C) Springer-Verlag Berlin Heidelberg 2012

\begin{abstract}
The trophic importance of bacteria to harpacticoid copepods in intertidal areas remains poorly understood, and so do the mechanisms of bacterial feeding. It is, for instance, unclear whether harpacticoids directly target bacterial cells or merely co-ingest them with substrates to which bacterial cells may be attached. Here, we investigate bacterial uptake and substrate requirement for four mud intertidal species (Microarthridion littorale, Platychelipus littoralis, Delavalia palustris and Nannopus palustris) by means of ${ }^{13} \mathrm{C}$-labeled bacteria and biomarker fatty acids (FA). Bacterial uptake strongly depended on grazing on a primary food source but bacterial ingestion rates were low, and no clear indication of copepods directly targeting bacteria was found. Delavalia was the only species that accumulated bacteria-derived FA and gained in polyunsaturated FA (PUFA) probably through bioconversion of bacteria-derived FA. In general, however, our results suggest that bacteria represent a relatively minor and lowquality food for intertidal harpacticoid copepods.
\end{abstract}

Communicated by M. Huettel.

Electronic supplementary material The online version of this article (doi:10.1007/s00227-012-2091-6) contains supplementary material, which is available to authorized users.

C. Cnudde $(\mid \underline{X \mid}) \cdot$ T. Moens $\cdot$ M. De Troch

Biology Department, Marine Biology, Ghent University,

Campus Sterre, Krijgslaan 281/S8, 9000 Ghent, Belgium

e-mail: clio.cnudde@UGent.be

\section{A. Willems}

Department of Biochemistry and Microbiology, Laboratory for Microbiology, Ghent University, K.L. Ledeganckstraat 35, 9000 Ghent, Belgium

\section{Introduction}

Interest in bacterivory in benthic food webs is closely linked to the need to understand the fate of benthic bacterial biomass. Benthic bacterial densities by far outnumber pelagic densities (Schmidt et al. 1998). The bacterial component of aquatic ecosystems is classically viewed as the main driver of organic matter degradation and nutrient remineralization processes (Azam et al. 1983). In addition, in pelagic systems, a 'feedback loop' from heterotrophic bacteria to the grazer food web, with flagellates as the principal bacterivores, has been demonstrated (microbial loop concept, Azam et al 1983). In marine sediments, bacterivorous protozoans can potentially structure the bacterial community (Kemp 1988; Epstein and Shiaris 1992; Hondeveld et al. 1992; Epstein 1997). In addition to microbenthos, organisms in other size classes, that is, the meio- and macrobenthos, may graze on bacterial biomass. Quantitative information on meiobenthic bacterivory is scant and has been estimated to remove $0.03-6.5 \%$ of bacterial standing stock per day (Epstein and Shiaris 1992; Epstein 1997; van Oevelen et al. 2006; Pascal et al. 2009). Furthermore, these 'bulk' rates of bacterivory may conceal more specific meiobenthos-bacteria interactions. Speciesspecific responses toward, and feeding selectivity among, different bacterial strains refute indiscriminate feeding behavior of nematodes (Montagna et al. 1995; Moens et al. 1999a) and harpacticoid copepods (Rieper 1978, 1982; Vandenberghe and Bergmans 1981; Carman and Thistle 1985; Dahms et al. 2007) on bacteria. Moreover, De Troch et al. (2009) illustrated the close relationship between harpacticoid copepods and bacteria on their fecal pellets. Mechanisms as bacterial gardening and trophic upgrading underline the potential role of bacteria at the basis of marine food web. 
Nevertheless, several basic questions on harpacticoid bacterivory remain poorly studied: (1) Are bacteria an essential component of the harpacticoid diet? and (2) Are bacteria ingested directly or merely co-ingested during the uptake of substrates with attached bacteria, such as sediment grains or diatoms? Harpacticoid copepods are an important link to higher trophic levels (Fujiwara and Highsmith 1997), but the contribution of bacteria to the nutritional status of copepods remains largely unknown. The work of Rieper (1978) formed a baseline study for the role of bacterivory by copepods. Later on, Souza-Santos et al. $(1996,1999)$ underlined the role of bacteria associated with diatoms to rear copepods and the use of bacteria as a potential food source. Harpacticoid copepods are rich in polyunsaturated fatty acids such as EPA (eicosapentaenoic acid) and DHA (docosahexaenoic acid) which are essential to their consumers (e.g., juvenile fish) and which they probably largely obtain from consumption of diatoms or other 'high-quality' food sources such as PUFA-rich dinoflagellates (Veloza et al. 2006; Chen et al. 2012). Bacteria generally lack these fatty acids and are therefore considered a low-quality food source (Chen et al. 2012), even though Rieper (1978) observed 'normal' copepod growth and reproduction on an exclusive diet of bacteria. On the other hand, planktonic and benthic copepods are known to produce these vital fatty acids through bioconversion of short-chain FA to long-chain FA (Desvilettes et al. 1997; De Troch et al. 2012).

In addition, it remains unclear whether copepods directly target bacterial cells or merely co-ingest them while feeding on other sources. Marine sediments contain various types of bacteria-rich sources, from macroalgae (Hicks 1977) and microalgae (Sapp et al. 2008) to phytodetritus (Perlmutter and Meyer 1991), animal carcasses (Tang et al. 2006), fecal pellets (De Troch et al. 2010) and sediment grains (Griebler et al. 2001). Hicks (1977) and Perlmutter and Meyer (1991) indicated that not the substrate but the substrate-bound bacteria attract copepods. Therefore, the present study aims to unravel the assimilation of bacterial carbon in relation to the presence of substrate. Assimilation of bacterial carbon will be quantified by means of trophic markers.

Direct measurement of grazing through the use of biomarkers has become widely applied in feeding ecology studies (see reviews by Boecklen et al. 2011; Kelly and Scheibling 2012). Combining trophic markers like stable isotopes and fatty acid profiles offers new opportunities to unravel trophic interactions at the basal level of marine food webs such as the bacteria-meiofauna link. Carbon isotopes may offer tools for a direct measurement of the assimilation of bacterial carbon, while fatty acid contents of grazers are indicative of the grazer's nutritional condition after feeding on a bacterial diet.
The specific objectives of the present study were (1) to evaluate the nutritional value of bacteria for harpacticoid copepods; (2) to assess whether bacterivory is copepod species-specific; (3) to assess whether bacterivory by harpacticoid copepods is an independent feeding strategy or merely a passive consequence of the ingestion of substrata: and (4) to test whether the requirement for any substrate is purely physical (only bacteria attached to larger particles can be ingested) or food-quality dependent (only bacteria attached to high-quality food particles can be ingested). Bacterivory was estimated by means of ${ }^{13} \mathrm{C}$ labeled bacteria and by fatty acid analysis. The third and fourth objectives were achieved by conducting a laboratory experiment in which copepods were incubated with bacteria in the absence and presence of sediment or diatoms as colonizable substrate. Species-specific differences in bacterivory were assessed by comparing the responses of four naturally co-occurring copepod species from a temperate salt marsh intertidal community.

\section{Materials and methods}

\section{Harpacticoid copepod species}

Copepods were collected from silty sediments of a small intertidal creek in the Paulina salt marsh in the Westerschelde estuary (SW Netherlands, $51^{\circ} 20^{\prime} 55.4^{\prime \prime} \mathrm{N}$, $3^{\circ} 43^{\prime} 20.4^{\prime \prime} \mathrm{E}$ ). In total, four harpacticoid copepod species with distinct differences in body morphology (body shape and size) and motility/emergence behavior, and belonging to different families, were selected. Two epibenthic harpacticoid species were included: Microarthridion littorale (family Tachidiidae) and Platychelipus littoralis (family Laophontidae). The former is small $(\sim 0.5 \mathrm{~mm}$ length, Lang 1948) and an active swimmer in near-bottom water (McCall 1992). The latter is a larger $(\sim 0.9 \mathrm{~mm}$ length, Lang 1948), sluggish, non-swimming copepod (C. Cnudde pers observ). The two other species, Nannopus palustris (family Huntemanniidae) and Delavalia palustris (formerly known as Stenhelia palustris, family Miraciidae), are large epi-endobenthic copepods ( $\sim 0.6-0.8 \mathrm{~mm}$ length. Lang 1948). Nannopus is a burrower (Santos et al. 2003), while Delavalia is a tube-dweller and tube-builder (Nehring 1993); both species have good swimming abilities and are quite mobile (C. Cnudde pers observ). Copepod species will further be referred to by their genus names. All copepod species were field-caught 2 days before the start of the experiment and extracted alive from the sediment using a mixed technique of sediment decantation and extraction based on their movement toward white light. Copepods were washed multiple times in sterile artificial seawater (Instant Ocean synthetic salt, salinity: 28, filtered 
over $0.2 \mu \mathrm{m}$ Millipore filters and autoclaved) (henceforth referred to as 'sterile ASW') and starved for $24 \mathrm{~h}$. Finally, copepods were washed once more in sterile ASW before introducing them into the experimental microcosms. Only adult, non-gravid specimens were selected, and both sexes were represented in the same proportions as in the field samples.

\section{Bacterial cultures}

Within $3 \mathrm{~h}$ after sediment collection, a bacterial suspension was prepared by adding $10 \mathrm{~mL}$ sterile artificial seawater (ASW, Instant Ocean synthetic salt, salinity: 28) to a small sediment aliquot ( $5 \mathrm{~mL}$ wet sediment) and thoroughly vortexing and shaking by hand; this mixture was finally filtered over a 3- $\mu \mathrm{m}$ Millipore filter to remove flagellates and eukaryotes. From $100 \mu \mathrm{L}$ of the obtained bacterial suspension, a $10^{-1}-10^{-5}$ dilution series in ASW was prepared and inoculated on marine agar (Marine Broth 2216. Difco ${ }^{\mathrm{TM}}$ ) and incubated for 7 days at $20^{\circ} \mathrm{C}$ in the dark. Dilutions $10^{-2}$ and $10^{-4}$ showed well-isolated colonies, different arrays of colony morphologies and substantially higher colony diversities than other dilutions. These dilutions resulted in colonies of different color (e.g., white, pink, yellow), shape (circular, irregular), elevation (raised, convex, flat) and colony margin (entire, undulated, curled) as inspected under binocular. The $10^{-2}$ and $10^{-4}$ mixed cultures were harvested from the agar plates by means of a cell scraper, and both cultures were separately inoculated in a liquid growth medium consisting of autoclaved ASW (salinity: 28), beef extract (DIFCO, $3 \mathrm{~g} \mathrm{~L}^{-1}$ ) and bacto peptone (DIFCO, $5 \mathrm{~g} \mathrm{~L}^{-1}$ ). They were incubated for 3 days at $20{ }^{\circ} \mathrm{C}$ on a mechanical shaker. The cultures resulting from the $10^{-2}$ and $10^{-4}$ dilutions were harvested through centrifugation at $2.500 \mathrm{rpm}$ for $10 \mathrm{~min}$ and resuspended in new growth medium, which was 20 -fold diluted compared with the above-described medium, and to which $0.5 \mathrm{~g} \mathrm{~L}^{-1}{ }^{13} \mathrm{C}$ glucose (D-glucose, $\mathrm{U}_{-}^{13} \mathrm{C} 6,99 \%$, Cambridge Isotope Laboratories. Inc.) was added. As a control for the effectiveness of ${ }^{13} \mathrm{C}$-labeling, parallel bacterial cultures were incubated in an identical liquid medium with ${ }^{12} \mathrm{C}$ glucose. After $24 \mathrm{~h}$ of growth, the growth medium was replaced by sterile seawater to remove any remaining ${ }^{13} \mathrm{C}$. This labeling technique yielded a specific uptake (see further under 'Stable isotopes analysis') in the bacteria between 8.530 and $8.700 \%$ corresponding to ca 9.7 atom $\%$. Prior to the experiment, bacteria were repeatedly rinsed with sterile ASW to remove the bacterial growth medium, and absence of flagellate and ciliate was controlled using a phase-contrast microscope. Bacterial densities were estimated by epifluorescence microscopy after staining with $10 \mu \mathrm{g} \mathrm{mL}^{-1}$ DAPI (final concentration) for $10 \mathrm{~min}$, modified protocol after Porter and Feig (1980). It is clear that our bacterial inoculum differed from the natural bacterial community since the culturing and labeling steps on artificial media inevitably reduced bacterial diversity and also cell size of cultured bacteria could differ from the natural bacterial size range. We nevertheless advocate the use of cultured and prelabeled bacteria in laboratory experiments since this procedure yields much higher specific uptake of bacteria $\left(\delta^{13} \mathrm{C}>8,000 \%\right)$ due to high activity of bacterial cells in culture compared with direct labeling of uncultured sediment bacteria where only a minor proportion of bacteria are able to incorporate the label, allowing a more sensitive detection of low rates of bacterivory. Secondly, prelabeling the bacteria avoided potential biases such as unspecific labeling of copepods (due to direct ingestion of the suspended label or protist grazing) or ectosymbiotic bacteria of copepods (Carman 1990), making interpretation of grazer enrichment easier.

\section{Diatom culture}

The benthic diatom Seminavis robusta has repeatedly been shown to be a suitable food source for a variety of harpacticoid copepods (De Troch et al. 2008; Cnudde et al. 2011). Seminavis robusta strain 84 A was obtained from the diatom culture collection of the Laboratory for Protistology and Aquatic Ecology (Ghent University). The original strain was isolated from a sample collected in November 2000 from the 'Veerse Meer', a brackish water lake in Zeeland, The Netherlands (Chepurnov et al. 2002). At the time of our experiment, the cells measured $35.7 \pm 3.1 \mu \mathrm{m}$ in length. The diatom cultures were grown non-axenically in tissue culture flasks $\left(175 \mathrm{~cm}^{2}\right.$ surface) with $20 \mathrm{~mL} \mathrm{~L}^{-1}$ f/2 medium (Guillard 1975) based on sterile ASW (salinity: 28) during 10 days at $16-18{ }^{\circ} \mathrm{C}$ with a $12: 12$-h light:dark period and 25-50 $\mu \mathrm{mol}$ photons $\mathrm{m}^{-2} \mathrm{~s}^{-1}$.

At the start of the experiment, the diatom growth medium was replaced by sterile ASW to prevent any additional growth. Two additional washes were performed to remove loosely attached bacteria by centrifugation at $2.500 \mathrm{rpm}$ for $5 \mathrm{~min}$. Diatom cell densities were estimated under an inverted light microscope (Zeiss Axiovert 40C).

\section{Substrate experiment}

The aim of this experiment was to assess the dependence of direct bacterial feeding by harpacticoid copepods on the presence of a physical substrate, either another food source (diatoms) or a sediment matrix. Experimental microcosms contained only copepods and living bacteria and, depending on the treatment, sediment grains and/or diatoms. Indirect uptake of bacterial carbon, for instance through predation on bacterivorous ciliates and flagellates, was thus excluded. The two harpacticoid copepod species with the 
highest abundances in the field samples were used here, that is, Microarthridion and Platychelipus. In view of their different mobility and behavior (see above), we expected differences in their dependence on substrate presence. Microarthridion may feed more on suspended particles (Decho 1986), whereas Platychelipus is more constrained to feeding in the sediment matrix. As the latter only moves its appendages to feed and hardly changes its endobenthic position (C. Cnudde, pers observ), we expect it to be mainly dependent on food sources in the sediment. Bacterial uptake by the copepods was analyzed by providing a ${ }^{13} \mathrm{C}$-labeled bacterial mix into four treatments, corresponding to each of four different substrate conditions:

(1) without any substrate, so with the bacterial suspension and copepods directly added to Petri dishes (treatment B);

(2) in the presence of muffled sediment, a substrate without any nutritional value (treatment BS);

(3) in the presence of diatoms, a substrate with nutritional value to copepods (treatment $\mathrm{BD}$ );

(4) in the presence of both muffled sediment and diatoms (treatment BDS).

Each treatment was replicated four times. Petri dishes (diameter: $5.2 \mathrm{~cm}$ ) were filled with $15 \mathrm{~mL}$ of sterile ASW (salinity: 28). In the sediment treatments BS and BDS, a sediment layer of $2 \mathrm{~mm}$ thick (ca $3 \mathrm{~g}$ dry weight) was added to the Petri dishes. This sediment was pretreated at $550{ }^{\circ} \mathrm{C}$ for $4 \mathrm{~h}$ to remove all organic carbon, and homogenized. Treatments BD and BDS were supplied with diatoms at a density of $2.5 \times 10^{6}$ diatom cells/Petri dish. All experimental units received $1 \times 10^{11}{ }^{13} \mathrm{C}$-labeled bacterial cells. After allowing diatoms and bacteria to settle on the Petri dish or sediment surface, copepods were added. We used 45 and 60 specimens per Petri dish for Platychelipus and Microarthridion, respectively. Twenty specimens from each dish were used for stable isotope analysis, and the remaining copepods of the 4 replicate dishes were pooled into one sample for fatty acid analysis. The experimental units were incubated for 4 days in a climate room at $16-18{ }^{\circ} \mathrm{C}$ with a $12: 12$-h light:dark regime.

Time-series experiment

The aim of this experiment was to assess the nutritional value of bacteria for three harpacticoid copepod species by evaluating copepod fatty acid profiles as an index of copepod nutritional status, and by investigating the incorporation of bacteria-specific FA biomarkers in addition to measuring uptake of ${ }^{13} \mathrm{C}$-enriched bacterial biomass. Based on the outcome of the first experiment (see results section), we chose two incubation times of $4\left(\mathrm{~T}_{4}\right)$ and 9 days $\left(\mathrm{T}_{9}\right)$, respectively, the latter mainly because shifts in copepod FA patterns tended to become pronounced only after several days (De Troch pers comm).

Based on the low assimilation rates obtained in sediment treatments in the substrate experiment, we restricted the time-series experiment to the $\mathrm{B}$ and $\mathrm{BD}$ treatments. There were four replicates per treatment and time. All copepods of the fourth replicate were used for fatty acid analysis. The treatments were set up with three copepod species: Nannopus, Delavalia and Platychelipus, with 60 specimens per microcosm. Microarthridion was omitted from this experiment in view of its poor performance in the substrate experiment (see results section). Diatom and bacterial cultures were obtained as described before, starting from a new diatom stock culture and a freshly collected sediment sample, respectively. The same bacterial and diatom cell densities and incubation conditions were applied as described for the substrate experiment.

\section{Sample processing}

After assessing the mortality of copepods in each microcosm, samples of 15 (Platychelipus) or 20 (Microarthridion, Nannopus, Delavalia) copepod specimens from each replicate microcosm were prepared for stable isotope analysis. Copepods were washed in sterile ASW, starved overnight to empty their guts and temporarily stored at $-20{ }^{\circ} \mathrm{C}$ till further processing. Remaining copepods of these three replicates, together with all copepods of the fourth replicate, were pooled, cleaned while alive, and stored on a Whatman filter at $-80{ }^{\circ} \mathrm{C}$ for fatty acid extraction. This yielded 60-120 specimens per sample for fatty acid analysis. For each treatment, we thus had three independent samples for stable carbon isotope analysis and one for fatty acid analysis. Control fatty acid samples of diatoms, bacteria and copepods were prepared in triplicate at the beginning of the experiment $\left(\mathrm{T}_{0}\right)$.

After thawing, samples for isotope analysis were processed by rinsing copepods several times in MilliQ water to remove adhering particles. The copepods were transferred to aluminum capsules $(6 \times 2.5 \mathrm{~mm})$. The overall procedure was executed within $2 \mathrm{~h}$ after thawing to minimize leakage of ${ }^{13} \mathrm{C}$ from the copepod body (Moens et al. 1999b). Subsequently, the aluminum capsules were ovendried overnight at $60{ }^{\circ} \mathrm{C}$, pinched closed and stored under dry atmospheric conditions until analysis. Additionally, three capsules for stable isotope analysis were prepared with subsamples of the bacterial cultures.

Stable isotopes analysis

$\delta^{13} \mathrm{C}$ values and carbon content of samples were measured using an isotope ratio mass spectrometer (type Europa Integra) at the Davis Stable Isotope Facility (University of 
California, USA). Uptake of ${ }^{13} \mathrm{C}$ label is expressed as specific uptake $\left(\Delta \delta^{13} \mathrm{C}=\delta^{13} \mathrm{C}_{\text {sample }}-\delta^{13} \mathrm{C}_{\text {control }}\right)$ and as ${ }^{13} \mathrm{C}$ uptake per unit copepod biomass. The control signal refers to the $\delta^{13} \mathrm{C}$ value of the copepods or bacteria at time $\mathrm{T}_{0}$. These data were converted to carbon uptake according to Middelburg et al. (2000), expressed as total uptake of ${ }^{13} \mathrm{C}$ (I, in $\mu \mathrm{g}{ }^{13} \mathrm{C}$ ), calculated as the product of excess ${ }^{13} \mathrm{C}$ (above background, E) and mean individual copepod biomass (organic carbon) per sample. Excess ${ }^{13} \mathrm{C}$ is the difference between the fraction ${ }^{13} \mathrm{C}$ of the control $\left(\mathrm{F}_{\text {control }}\right)$ and the sample $\left(\mathrm{F}_{\text {sample }}\right)$, where $\mathrm{F}={ }^{13} \mathrm{C} /\left({ }^{13} \mathrm{C}+{ }^{12} \mathrm{C}\right)=\mathrm{R} /$ $(\mathrm{R}+1)$. The carbon isotope ratio $(\mathrm{R})$ was derived from the measured $\delta^{13} \mathrm{C}$ values as $\mathrm{R}=\left(\delta^{13} \mathrm{C} / 1000+1\right) \times \mathrm{R}_{\mathrm{VPDB}}$. with $R_{\mathrm{VPDB}}=0.0112372$. Subsequently, total ${ }^{13} \mathrm{C}$ uptake was converted to total bacterial carbon assimilation per unit copepod carbon (in $\mu \mathrm{g} \mathrm{C}$ ), calculated by dividing uptake I by sample biomass (organic carbon content) and taking into account the atomic $\%{ }^{13} \mathrm{C}$ in bacterial biomass $(9.7 \%)$. Individual carbon contents of the copepod species were, in decreasing order, $1.51 \pm 0.10,1.05 \pm 0.06$, $0.85 \pm 0.04$ and $0.55 \pm 0.02 \mu \mathrm{g} \mathrm{C}$ (mean $\pm 1 \mathrm{SD}, n=4$ ) for Platychelipus, Nannopus, Delavalia and Microarthridion, respectively.

\section{FA analysis}

Hydrolysis of total lipids of bacteria, diatoms and copepods and methylation to fatty acid methyl esters (FAME) was achieved by a modified one-step derivatization method after Abdulkadir and Tsuchiya (2008), De Troch et al. (2012). The boron trifluoride-methanol reagent was replaced by a $2.5 \% \mathrm{H}_{2} \mathrm{SO}_{4}$-methanol solution since $\mathrm{BF}_{3}$ methanol can cause artefacts or loss of PUFA (Eder 1995). The obtained FAME were analyzed using a gas chromatograph (HP $6890 \mathrm{~N}$ ) with a mass spectrometer (HP 5973). The samples were run in splitless mode (for copepods, $5 \mu \mathrm{L}$ injected per run) and split mode (for bacteria, $0.1 \mu \mathrm{L}$ injected per run), at an injector temperature of $250{ }^{\circ} \mathrm{C}$ using a HP88 column (Agilent J\&W. Agilent Co., USA). The oven temperature was programmed at $50^{\circ} \mathrm{C}$ for $2 \mathrm{~min}$, followed by a ramp at $25^{\circ} \mathrm{C} \min ^{-1}$ to $175^{\circ} \mathrm{C}$ and then a final ramp at $2{ }^{\circ} \mathrm{C} \min ^{-1}$ to $230{ }^{\circ} \mathrm{C}$ with a 4 -min hold. The FAME were identified by comparison with the retention times and mass spectra of authentic standards and mass spectral libraries (WILEY, NITS05), and analyzed with the software MSD ChemStation (Agilent Technologies). Quantification of individual FAME was accomplished by linear regression of the chromatographic peak areas and corresponding known concentrations (ranging from 5 to $150 \mu \mathrm{g} \mathrm{mL}^{-1}$ ) of external standards (Supelco \# 47885, Sigma-Aldrich Inc., USA).

Shorthand FA notations of the form $\mathrm{A}: \mathrm{B} \omega \mathrm{X}$ were used, where $A$ represents the number of carbon atoms, $B$ gives the number of double bonds, and $X$ gives the position of the double bond closest to the terminal methyl group (Guckert et al. 1985).

\section{Statistical data analysis}

Differences in bacterial carbon uptake by copepods and in copepod mortality among treatments were analyzed by means of two-way analysis of variance (ANOVA) for the substrate experiment with fixed factors 'copepod species' and 'substrate' and three-way analysis of variance for the time-series experiment with fixed factors 'copepod species', 'substrate' and 'time'. The Tukey's HSD post hoc test was applied to detect pairwise differences, using $95 \%$ confidence limits. Prior to ANOVA, Levene's test was used to check the assumption of homoscedasticity; if the data did not fulfill this requirement, data of carbon uptake and mortality were $\log _{(x+1)}$-transformed and arcsine-squareroot-transformed, respectively. All data analyses were performed using the software package $R$, version 2.14.1 ( $R$ Development Core Team 2009).

Differences in FA composition between food sources (bacteria and diatoms) and between natural copepods (copepods at $\mathrm{T}_{0}$ ), were analyzed using 1-factor PERMANOVA with, respectively, factor 'food' and 'copepod species', based on a Bray-Curtis resemblance matrix constructed from untransformed relative FA values. Depending on the number of unique permutations of each dataset, $P$-values $(p)$ or Monte Carlo $P$ values $\left(P_{\mathrm{MC}}\right)$ were interpreted. The assumption of homogeneity of the multivariate dispersions was checked using PERMDISP. FA responsible for group differentiation were identified using similarity percentage analysis (SLMPER). Principal coordinates analysis (PCO) using Bray-Curtis similarity $(n=21)$ was performed to visualize FA composition of copepods at $T_{0}, T_{4}$ and $T_{9}$. Individual $F A$ contributing highly to the variation explained by PCO were represented as vectors.

\section{Results}

\section{Substrate experiment}

Mortality after 4 days incubation (Table 1) differed between harpacticoid species and treatments ( $p<0.001$ for substrate, copepod species and interaction copepod $\times$ substrate). The mortality of Platychelipus was limited and independent of the substrate $(p>0.05)$. Microarthridion had a similar mortality as Platychelipus in the absence of sediment. but a very high mortality (i.e.. 96-100\%) in presence of sediment. Mortality in both species was not influenced by the presence of diatoms $(p>0.05)$. 
Table 1 Copepod mortality percentage $( \pm 1 \mathrm{SD}, n=4)$ in the substrate experiment and in the time-series experiment

\begin{tabular}{|c|c|c|c|c|}
\hline Mortality (\%) & B & $\mathrm{BD}$ & BS & BDS \\
\hline \multicolumn{5}{|c|}{ Substrate experiment } \\
\hline \multicolumn{5}{|l|}{ Platychelipus } \\
\hline $\mathrm{T}_{4}$ & $8( \pm 7)$ & $25( \pm 16)$ & $19( \pm 6)$ & $24( \pm 3$ \\
\hline \multicolumn{5}{|c|}{ Microarthridion } \\
\hline $\mathrm{T}_{4}$ & $13( \pm 9)$ & $12( \pm 3)$ & $100( \pm 0)$ & $96( \pm 3$ \\
\hline \multicolumn{5}{|c|}{ Time-series experiment } \\
\hline \multicolumn{5}{|c|}{ Platychelipus } \\
\hline $\mathrm{T}_{4}$ & $3( \pm 3)$ & $3( \pm 2)$ & & \\
\hline $\mathrm{T}_{9}$ & $18( \pm 7)$ & $2( \pm 2)$ & & \\
\hline \multicolumn{5}{|l|}{ Nannopus } \\
\hline $\mathrm{T}_{4}$ & $1( \pm 1)$ & $3( \pm 2)$ & & \\
\hline $\mathrm{T}_{9}$ & $6( \pm 3)$ & $2( \pm 2)$ & & \\
\hline \multicolumn{5}{|l|}{ Delavalia } \\
\hline $\mathrm{T}_{4}$ & $8( \pm 9)$ & $5( \pm 5)$ & & \\
\hline $\mathrm{T}_{9}$ & $34( \pm 12)$ & $9( \pm 5)$ & & \\
\hline
\end{tabular}
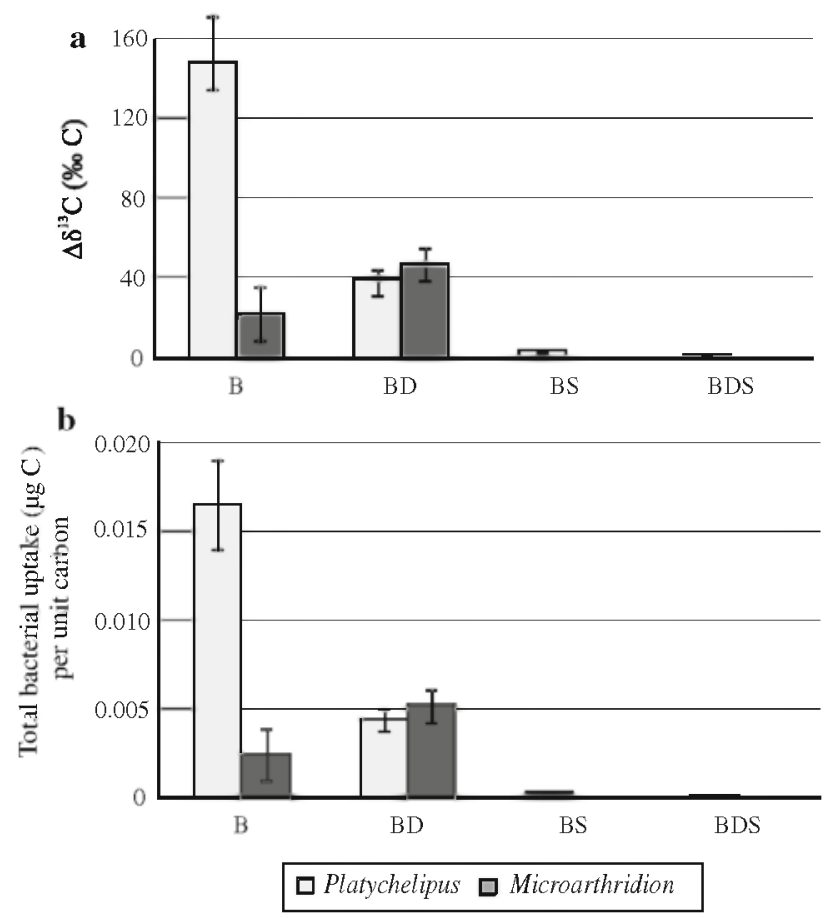

Fig. 1 Substrate-dependent assimilation of bacterial carbon (mean \pm 1 SD, $n=4$ ) by Platychelipus and Microarthridion after 4 days of grazing on a bacterial mixture without a primary substrate (treatment B) and in the presence of diatoms (treatment BD), sediment (treatment BS) and the combination diatoms + sediment (treatment BDS). Assimilation of bacterial carbon is expressed as (a) specific uptake $\Delta \delta^{13} \mathrm{C}$ and (b) total uptake of bacterial carbon per unit copepod carbon

The specific ${ }^{13} \mathrm{C}$ uptake levels $\left(\Delta \delta^{13} \mathrm{C}\right)$ of Platychelipus and Microarthridion (Fig. 1a) proved species-specific bacterial carbon uptake and its substrate dependence
( $p<0.005$ for factors copepod, substrate and copepod $\times$ substrate). Both copepod species were able to feed on bacteria in absence of a substrate (Fig. 1a, treatment B), though Platychelipus reached a significantly higher specific uptake than Microarthridion $(p<0.001)$. The sediment substrate (Fig. 1a, treatments BS and BDS) almost completely inhibited bacterial feeding: specific ${ }^{13} \mathrm{C}$ uptake was low for Platychelipus while most Microarthridion died in treatments with sediment (up to $100 \%$ mortality, Table 1). In the presence of diatoms, equal bacterial assimilation was observed for both species $(p>0.05)$. However, presence of diatoms enhanced bacterial assimilation by Microarthridion (post hoc test. $p<0.01$ ) while the opposite was observed for Platychelipus (post hoc test, $p<0.001$ ). The same trends were observed for the total bacterial carbon uptake per unit copepod carbon (Fig. 1b). Overall, highest bacterial uptake per unit carbon was found for Platychelipus in absence of a substrate, while Microarthridion had a much lower assimilation than Platychelipus in the B treatment, but an equal uptake in the $\mathrm{BD}$ treatment (Fig. 1b).

Total FA content (fatty acid content) of both copepods decreased in both treatments with bacteria as the only food source (Table 2, B and BS). Platychelipus lost 7 and $11 \%$, respectively, of its initial fatty acids in the B and BS treatment, and Microarthridion lost $25 \%$ in the B treatment. In bacteria-diatom treatments (BD and BDS), total FA content of Platychelipus doubled $(+122 \%)$ and quadruplicated $(+287 \%)$, respectively, without and with sediment, while Microarthridion gained $79 \%$ in the BD treatment compared with the control.

Time-series experiment

After 4 days of feeding, mortality did not differ between copepod species $(p>0.05)$, or food treatments $(p>0.05)$ (Table 1). Mean mortality was $4 \pm 4 \%$ (mean \pm 1 SD, $n=21$ ). Mortality remained unaltered over time in the bacteria-diatom treatment (post hoc test, $p>0.05$ ). In treatments with only bacteria, mortality of the copepod species Platychelipus and Delavalia had increased after 9 days, with mean mortalities of $18 \pm 7 \%$ and $34 \pm 12 \%$ $(n=4)$, respectively (post hoc test, $0.05<p<0.1$ and $p<0.01$, respectively). Mortality of Nannopus remained low $(6 \pm 3 \%, p>0.05)$.

\section{${ }^{13} \mathrm{C}$ uptake and total fatty acid content as tracers of bacterivory}

At the start of the experiment, copepods exhibited species-specific differences in their natural $\delta^{13} \mathrm{C}$ (1-way ANOVA, $p<0.001$, post hoc test $p<0.05)$ : $-14.9 \pm$ $0.2 \%,-16.1 \pm 0.4 \%$ and $-17.1 \pm 0.3 \%(n=3)$ for 
Table 2 Total fatty acid content (FA) of copepods from the substrate experiment and time-series experiment, before (control) and after grazing (treatments B, BD, BS, BDS) in comparison with their initial fatty acid content (control) before grazing (\%)

Total FA $(\%)$

\begin{tabular}{|c|c|}
\hline Substrate ex & \\
\hline Platycheli & \\
\hline Control & 0 \\
\hline B & -7 \\
\hline $\mathrm{BD}$ & +122 \\
\hline BS & -11 \\
\hline BDS & +257 \\
\hline Microarth & \\
\hline Control & 0 \\
\hline B & -25 \\
\hline $\mathrm{BD}$ & +79 \\
\hline Time-series & \\
\hline Platycheli & \\
\hline Control & 0 \\
\hline $\mathrm{B}-\mathrm{T}_{4}$ & -41 \\
\hline $\mathrm{B}-\mathrm{T}_{9}$ & -56 \\
\hline $\mathrm{BD}-\mathrm{T}_{4}$ & +71 \\
\hline $\mathrm{BD}-\mathrm{T}_{9}$ & +117 \\
\hline Nannopus & \\
\hline Control & 0 \\
\hline $\mathrm{B}-\mathrm{T}_{4}$ & -59 \\
\hline $\mathrm{B}-\mathrm{T}_{9}$ & -61 \\
\hline $\mathrm{BD}-\mathrm{T}_{4}$ & -44 \\
\hline $\mathrm{BD} \mathrm{T}_{9}$ & -31 \\
\hline Delavalia & \\
\hline Control & 0 \\
\hline $\mathrm{B}-\mathrm{T}_{4}$ & -27 \\
\hline $\mathrm{B}-\mathrm{T}_{9}$ & +21 \\
\hline $\mathrm{BD}-\mathrm{T}_{4}$ & +67 \\
\hline $\mathrm{BD}-\mathrm{T}_{9}$ & +240 \\
\hline
\end{tabular}

Platychelipus, Nannopus and Delavalia, respectively. At the end of the experiment (at $\mathrm{T}_{9}$ ), all three copepod species showed ${ }^{13} \mathrm{C}$ enrichment (Fig. 2) resulting from uptake of labeled bacteria. Overall, a three-way ANOVA showed a copepod species-specific uptake of bacteria, significant differences depending on substrate type and over time and significant pairwise interactions between the factors (Table 3, factors copepod species, substrate and time, $p<0.001)$. More specifically, copepod specific uptake is found in the B treatment (post hoc test copepod $\times$ substrate, $p<0.01$ ). After 4 days feeding (Fig. $2 \mathrm{a}, \mathrm{T}_{4}$ ), Delavalia showed the lowest specific uptake $(81 \pm 44 \%)$, which was nevertheless still higher than the specific uptake by Microarthridion $(22 \pm 13 \%)$ in the corresponding treatment of the substrate experiment. The specific uptake by Platychelipus was the highest $(196 \pm 48 \%)$ among the three species and closely resembled that in the substrate experiment (148 $\pm 22 \%$ ) (Fig. 1a). This copepod specific pattern was also present after 9 days feeding. In the presence of diatoms, bacterial assimilation for Platychelipus and Delavalia was significantly higher than for Nannopus (post hoc test, copepod $\times$ substrate, $p<0.001$ ). Prolongation of the feeding period to 9 days (Fig. 2a) did not result in any significant increase or decrease in ${ }^{13} \mathrm{C}$ uptake in the B treatment for any of the three species (post hoc test substrate $\times$ time, $p>0.05$ ). In the $\mathrm{BD}$ treatment, ${ }^{13} \mathrm{C}$ enrichment of Platychelipus and especially Delavalia strongly increased with time (Fig. 2a and post hoc test copepod $\times$ time, respectively; $p<0.01$ and $p<0.001$ ). Due to diatom presence, total bacterial uptake per unit copepod carbon (Fig. 2b) doubled for Platychelipus (from 0.03 to almost $0.06 \mu \mathrm{g} \mathrm{C}_{\text {bact }}$ per $\mu \mathrm{g} \mathrm{C}_{\text {cop }}$ ) and quintupled for Delavalia (from 0.01 to $0.06 \mu \mathrm{g} \mathrm{C}_{\text {bact }}$ per $\mu \mathrm{g} \mathrm{C}_{\text {cop }}$ ). For Nannopus, the uptake of bacteria was twice as high (from 0.015 to almost $0.03 \mu \mathrm{g} \mathrm{C}_{\text {bact }}$ per $\mu g \mathrm{C}_{\text {cop }}$ ) in the presence of diatoms but of no significance, not time-related or substrate-dependent.

Copepods showed an important change in total FA content (Table 2) compared with their initial FA content ('control'). Platychelipus and Nannopus in the B treatment showed a reduction in FA content during the first 4 days (up to $-59 \%$ ) and an additional but minor loss during the following days (up to day 9) (Table 2). Delavalia exhibited a comparatively small decrease in FA content after 4 days $(-27 \%)$, and after 9 days, it even had a $21 \%$ higher FA content than the $\mathrm{T}_{0}$ specimens. Species-specific differences also occurred in the BD treatment: Delavalia and Platychelipus showed a considerable increase in FA content by $67-71 \%$ and by up to $240 \%$, respectively, after 4 and 9 days, while Nannopus showed loss of FA in both treatments (B, BD), independent of the duration of the incubation.

\section{Individual fatty acid biomarkers}

FA composition clearly differed between bacteria and diatoms (Fig. 3 and 1-factor PERMANOVA main test, pseudo-F 185.54, 10 unique perm., $P_{\mathrm{MC}}=0.001$ ), with a dissimilarity of $50.5 \%$ (SIMPER, data not shown). C16:1 $\omega 7$ and C16:0 (Fig. 3, ESM Table 1) were the main FA (with relative abundance $>10 \%$ ) shared by both food sources. Major bacteria-specific FA, henceforth referred to as bacterial biomarkers, were $\mathrm{C} 18: 1 \omega 9$ (relative abundance $37.6 \%$, also found in diatoms but in very low amounts) and $\mathrm{C} 17: 1 \omega 7$ (relative abundance $10.7 \%$ ), whereas C20:5 13 (eicosapentaenoic acid, EPA, relative abundance $14.3 \%$ ) was a diatom-specific FA ('diatom biomarker') in our experiment. Other biomarkers, though of lower relative 

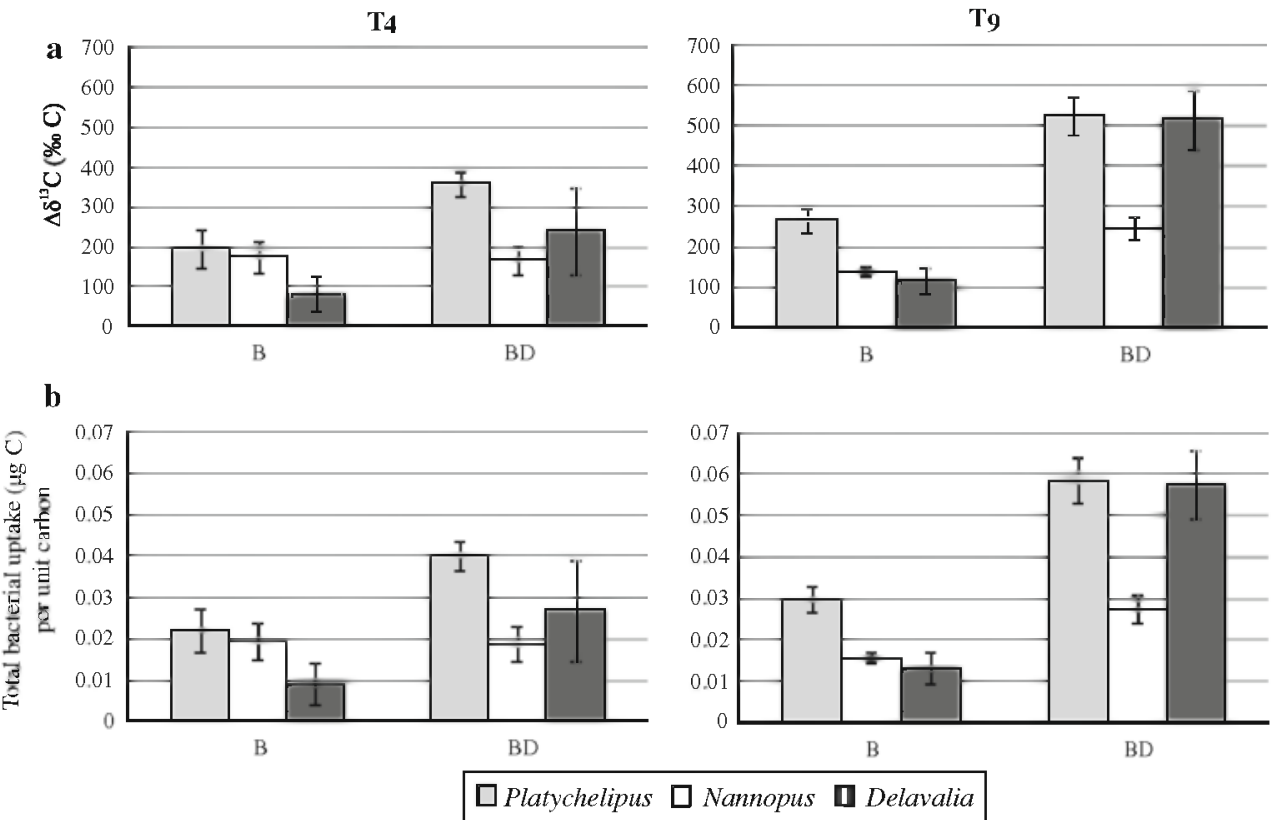

Fig. 2 Assimilation of bacterial carbon (mean $\pm 1 \mathrm{SD}, n=3$ ) by Platychelipus, Nannopus and Delavalia after 4 days $\left(\mathrm{T}_{4}\right)$ and 9 days feeding $\left(T_{9}\right)$, in the absence of a substrate (treatment $B$ ) and in the

presence of a diatom substrate (treatment BD). Assimilation is expressed as (a) specific uptake $\Delta \delta^{13} \mathrm{C}$ and (b) total uptake of bacterial carbon per unit copepod carbon
Table 3 Results from threeway ANOVA with the factors copepod species ("cop"), substrate ("sub") and time ("time")

Significance codes $* p<0.05$, $* * p<0.01, * * * p<0.001$

abundance (2-10\%) (Fig. 3), were C17:0 for bacteria and

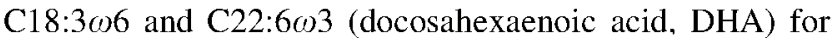
diatoms.

The three copepod species, while originating from the same sampling station, had distinct FA compositions at $\mathrm{T}_{0}$ (Fig. 3 and 1-factor PERMANOVA main test, pseudo$F=8.77, p=0.0036$, see also ESM Table 1 ). The main differences were found between Delavalia on the one hand and Platychelipus and Nannopus on the other (Table 4). Delavalia contained higher amounts of C17:0, C17:1 107 and also C15:0 (Fig. 3). Odd-numbered FA in general, also including 15:1, are FA produced by marine bacteria (Kelly and Scheibling 2012). The elevated amounts of these three bacteria-derived FA substantially contributed to the dissimilarity in FA composition between Delavalia and
Platychelipus + Nannopus (Table 5). The total relative

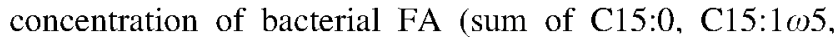
C17:0 and C17:167) for Delavalia, Nannopus and Platychelipus was, respectively, $23.4 \pm 2.5 \%, 4.8 \pm$ $0.6 \%$ and $1.8 \pm 0.7 \%(n=3)$, confirming that Delavalia has a stronger bacterial signature compared to the other species $(p<0.001)$.

FA composition of experimental copepods deviated from their initial FA composition $\left(\mathrm{T}_{0}\right)$, as shown by the PCO plot (Fig. 4). The first two axes of the PCO explained more than $80 \%$ of the variation in copepod FA patterns and $11 \mathrm{FA}$, represented as vectors, are recognized as main contributors to changes in FA patterns. Changes in FA composition differed depending on the copepod species and on the food treatment (Fig. 4). Copepod species fed 

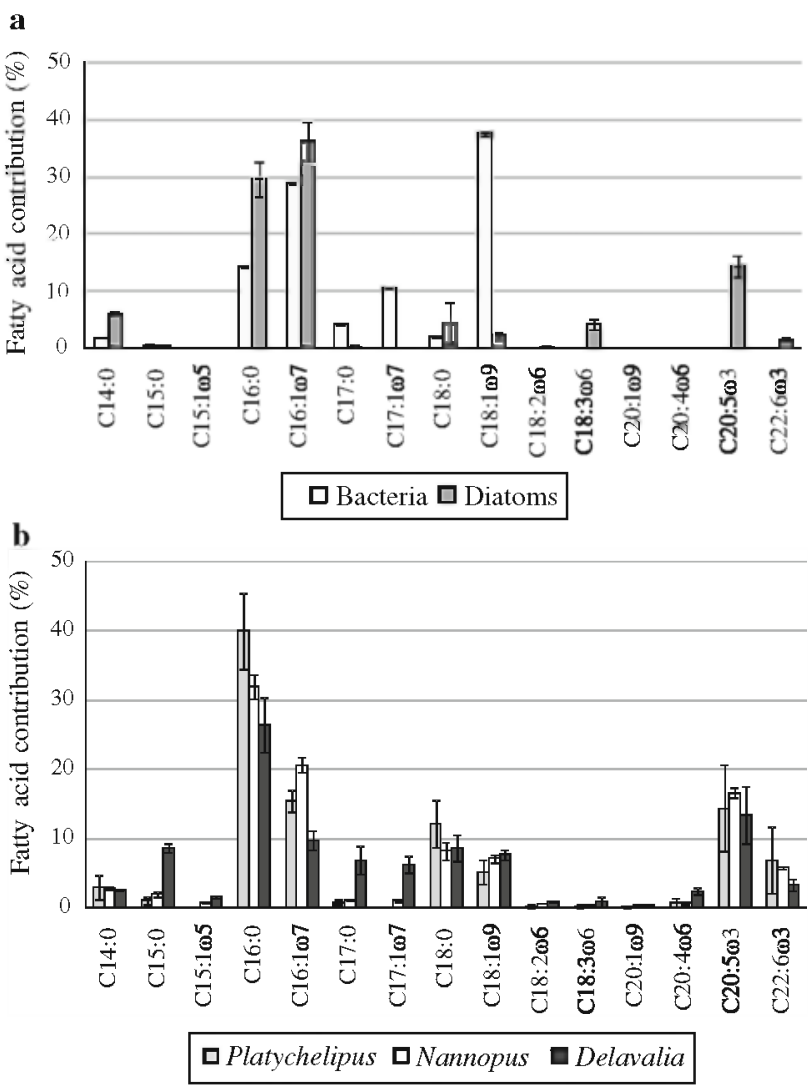

Table 5 Partial result from SIMPER analysis: dissimilarity percentages between the fatty acid composition of copepod species at $\mathrm{T}_{0}$ based on Bray-Curtis similarity

\begin{tabular}{lc}
\hline Fatty acids & Contrib\% \\
\hline DEL-NAN & \\
C16:1 $\omega 7$ & 23.26 \\
C15:0 & 14.49 \\
C17:0 & 12.30 \\
C16:0 & 12.08 \\
C17:1 $\omega 7$ & 11.14 \\
DEL-PLA & \\
C16:0 & 22.13 \\
C15:0 & 12.61 \\
C17:1 $\omega 7$ & 10.29 \\
C17:0 & 9.89 \\
C16:1 $\omega 7$ & 9.29 \\
C20:5 $\omega 3$ & 8.43 \\
NAN-PLA & \\
C16:0 & 24.51 \\
C16:1 $\omega 7$ & 15.95 \\
C20:5 $\omega 3$ & 13.02 \\
C18:0 & 12.80 \\
C22:6 63 & 9.96 \\
\hline
\end{tabular}

Fatty acids contributing to dissimilarity between copepod FA composition are presented (Contrib\%), using a cutoff of $70 \%$

Fig. 3 Relative fatty acid composition (\%) of (a) the food sources (bacteria and diatom monoculture) and of (b) the copepod species at time $\mathbf{T}_{0}$

Table 4 Results from one-factor PERMANOVA analysis: pairwise tests of copepod species at $T_{0}$ for differences in natural fatty acid composition, based on the Bray-Curtis resemblance matrix

\begin{tabular}{lllll}
\hline Groups & $\mathrm{t}$ & $P$ & Unique perms & $\mathrm{P}_{\mathrm{MC}}$ \\
\hline DEL-NAN & 4.1788 & 0.1015 & 10 & $0.0034^{* *}$ \\
DEL-PLA & 3.1305 & 0.0974 & 10 & $0.0098^{* *}$ \\
NAN-PLA & 1.7609 & 0.1035 & 10 & 0.0955 \\
\hline
\end{tabular}

Significant differences among copepod species are deduced from Monte Carlo $P$ values $\left(P_{\mathrm{MC}}\right)$

Significance codes $* P_{\mathrm{MC}}<0.05, * * P_{\mathrm{MC}}<0.01, * * * P_{\mathrm{MC}}<0.001$

with bacteria showed limited FA changes compared with their original FA pattern. Copepods fed with diatoms grouped together at the upper-right side of the PCO, showing elevated levels of $\mathrm{C} 16: 1 \omega 7$ (found in both diatoms and bacteria) and three PUFA (C18:3 $\omega 6, \mathrm{C} 20: 5 \omega 3$ and 22:6w3), especially for Delavalia and Platychelipus. The detailed changes of these and other FA are visualized in Fig. 5. In the B treatment, only Delavalia showed increased levels of FA in contrast to the $\mathrm{T}_{0}$ levels and this after 9 days: $\mathrm{C} 16: 1 \omega 7$, the bacterial biomarker $\mathrm{C} 18: 1 \omega 9$ and PUFA (e.g., EPA, DHA). PUFA were not obtained by

feeding since the bacterial food lacked PUFA, so bioconversion must have occurred. Other species showed strong reductions of almost all $\mathrm{FA}$, including the listed biomarkers and PUFA. In BD treatments (Fig. 5), copepod FA composition was more profoundly influenced, in particular for Platychelipus and Delavalia, showing elevated levels of both $\mathrm{C} 16: 0$ and $\mathrm{C} 16: 1 \omega 7$, of diatom biomarker FA (C20:5 $\omega 3, \mathrm{C} 18: 3 \omega 6, \mathrm{C} 22: 6 \omega 3, \mathrm{C} 14: 0)$ and of the bacterial biomarker $\mathrm{C} 18: 1 \omega 9$. No gain in $\mathrm{C} 17: 1 \omega 7$, an exclusive bacterial biomarker, was observed. These FA changes were already visible after 4 days of feeding (Fig. 5). For $D e$ lavalia in the BD treatment, FA levels increased until the end of the incubation (Fig. 5. left-right panels), whereas they leveled off after 4 days in Platychelipus and decreased from the start in Nannopus.

\section{Discussion}

Substrate-dependent bacterivory

Harpacticoids are considered substrate browsers (Marcotte 1977; Hicks and Coull 1983; Huys et al. 1996), except for the two more primitive families Longipediidae and Canuellidae which are filter-feeders. Harpacticoid copepods collect their food from so-called large substrates (such as 

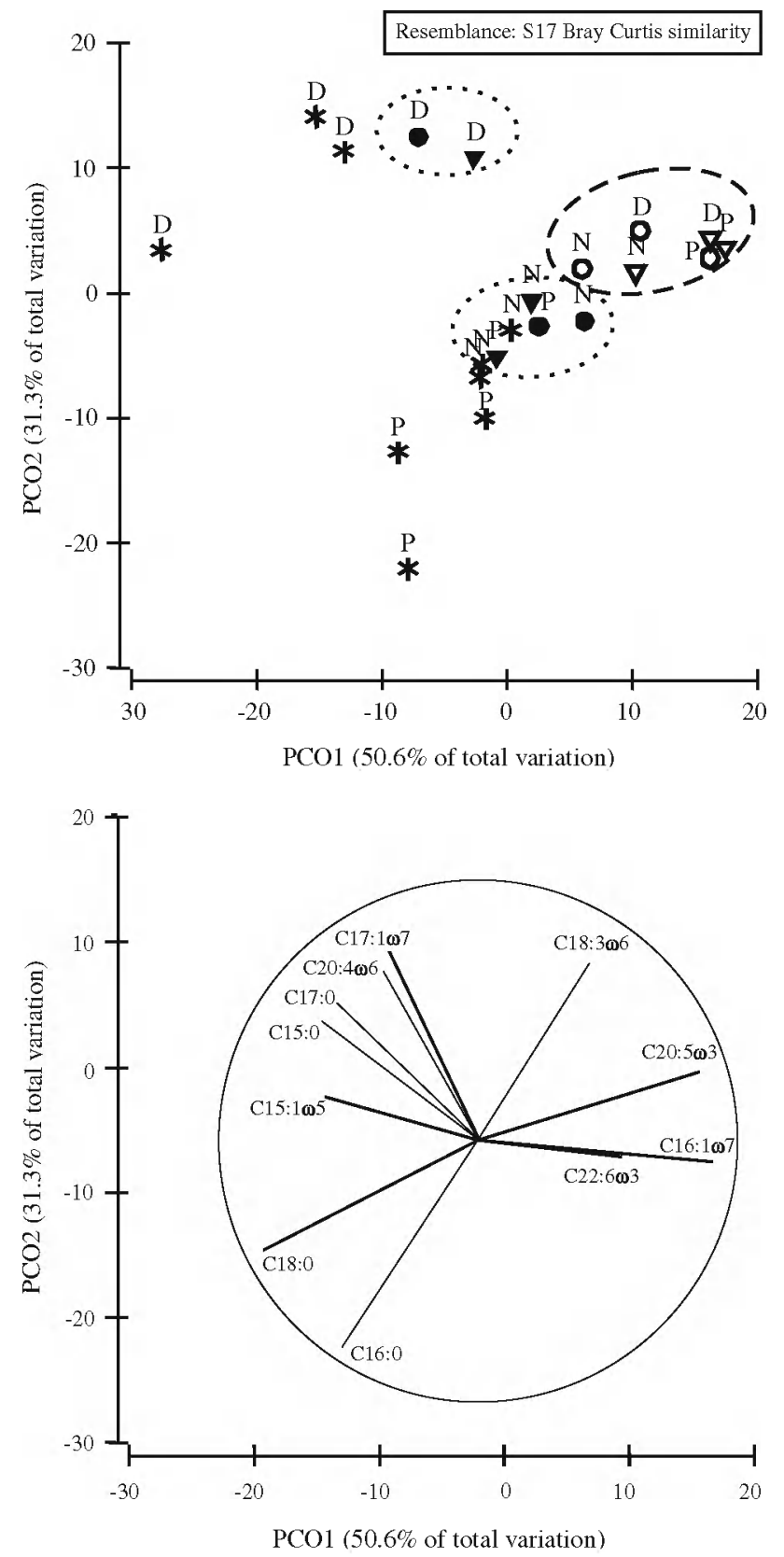

Fig. 4 Principal coordinate (PCO) analysis of Platychelipus (P), Nannopus (N) and Delavalia (D) based on their natural relative fatty acid composition (asterisk) and composition after experimental grazing during 4 days (circle) and 9 days (inverted triangle) (filled symbol-grazing on bacteria; open symbol-grazing on bacteria and diatoms). Changes in copepod FA profiles after feeding on bacteria and diatoms are encircled by dotted and broken lines, respectively. The vectors represent individual fatty acids with a Spearman rank correlations of $>50 \%$ to one of the first two PCO axes

sediment and detrital particles) by point-feeding, edgescraping, sweeping food of a planar surface into their mouth or scraping food from depressions in sand particles. Feeding on smaller substrates (solid-feeding) is done by crushing the food, by sphere-cleaning where food is cleaned from surfaces by rotating spheres or organic floccules in the copepod's mouth, and by rubble-sorting where food is cleaned of organic debris by passing it over the mouth parts and organic debris is passed back through the arch of the swimming legs.

To our knowledge, no studies have specifically addressed the requirement of a physical substrate during bacterial feeding of harpacticoid copepods vs direct bacterial targeting. In calanoid copepods, filter-feeding is a common mechanism for capturing small-sized particles, but even for this group, only a few studies have focused on ingestion of particles smaller than $2 \mu \mathrm{m}$ (Berggreen et al. 1988; Turner and Tester 1992; Roff et al. 1995). In the present study, we focused on bacterial grazing by harpacticoid copepods in treatments with and without a substrate (sediment or diatoms) and further tested whether it is merely the physical presence of the substrate that matters or its nutritional value. Our study shows that all tested harpacticoid copepods ingest and assimilate bacteria in absence of a substrate, albeit at species-specific and generally low rates. This low bacterial assimilation could be linked to morphological constraints on feeding. limiting capture efficiency of free-living bacteria. However, only a few studies (Seifried and Durbaum 2000; Michels and Schnack-Schiel 2005; De Troch et al. 2006a) have linked morphology of the harpacticoid feeding apparatus to food utilization but in general, mouth morphology is still not applied as a predictor of food utilization by harpacticoids (De Troch et al. 2006a). It seems plausible, though, that harpacticoids are incapable of actively capturing microparticles $(<5 \mu \mathrm{m})$, implying that bacterivory is passive (Ling and Alldredge 2003). For example, for the non-motile Platychelipus, bacterial ingestion could be achieved by flapping of the feeding appendages (pers obs). Alternatively, however, bacteria may be actively ingested by grazing on largersized bacterial aggregates or on fecal pellets, a substratum produced by the copepods themselves and which rapidly becomes coated with bacteria (De Troch et al. 2009, 2010). Based on dual labeling (both $\mathrm{N}$ and C), Leroy et al. (2012) found that larvae of the gastropod Crepidula fornicata were able to ingest particles of typical bacterial size. As in the present study, their results however suggested that the gastropod larvae preferentially used diatoms and showed that the supply of free bacteria did not alter the uptake of diatoms. They further concluded that bacteria may constitute a complementary resource for the larvae when phytoplankton is abundant and may become a substitute resource at low phytoplankton concentrations.

The presence of sediment as a substratum had a negative impact on bacterial uptake. Microarthridion suffered from very high mortality in treatments with sediment. while Platychelipus did not. This outcome can likely be subscribed to the ecology (motility) of the copepod species. The swimming species Microarthridion can easily avoid 

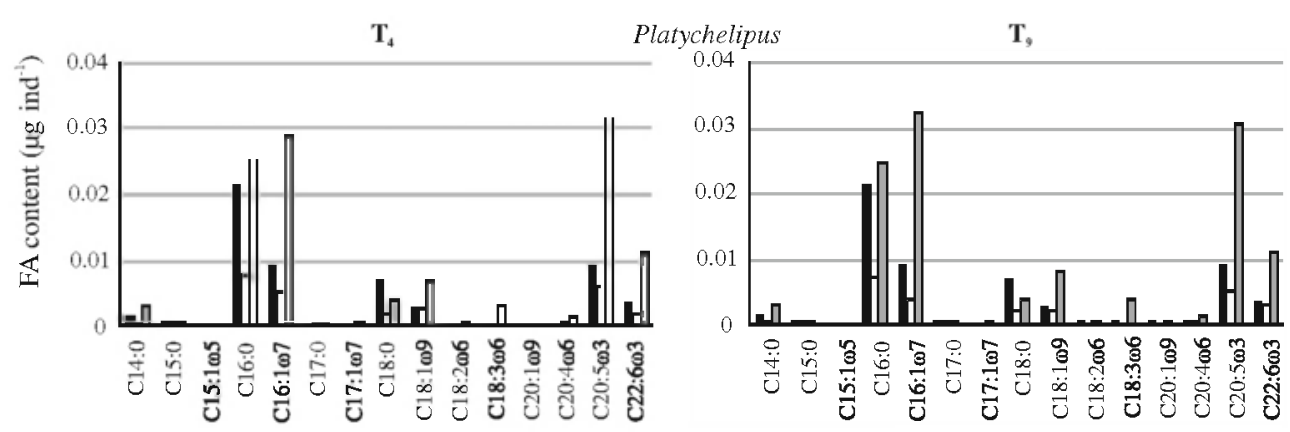

Nannopus
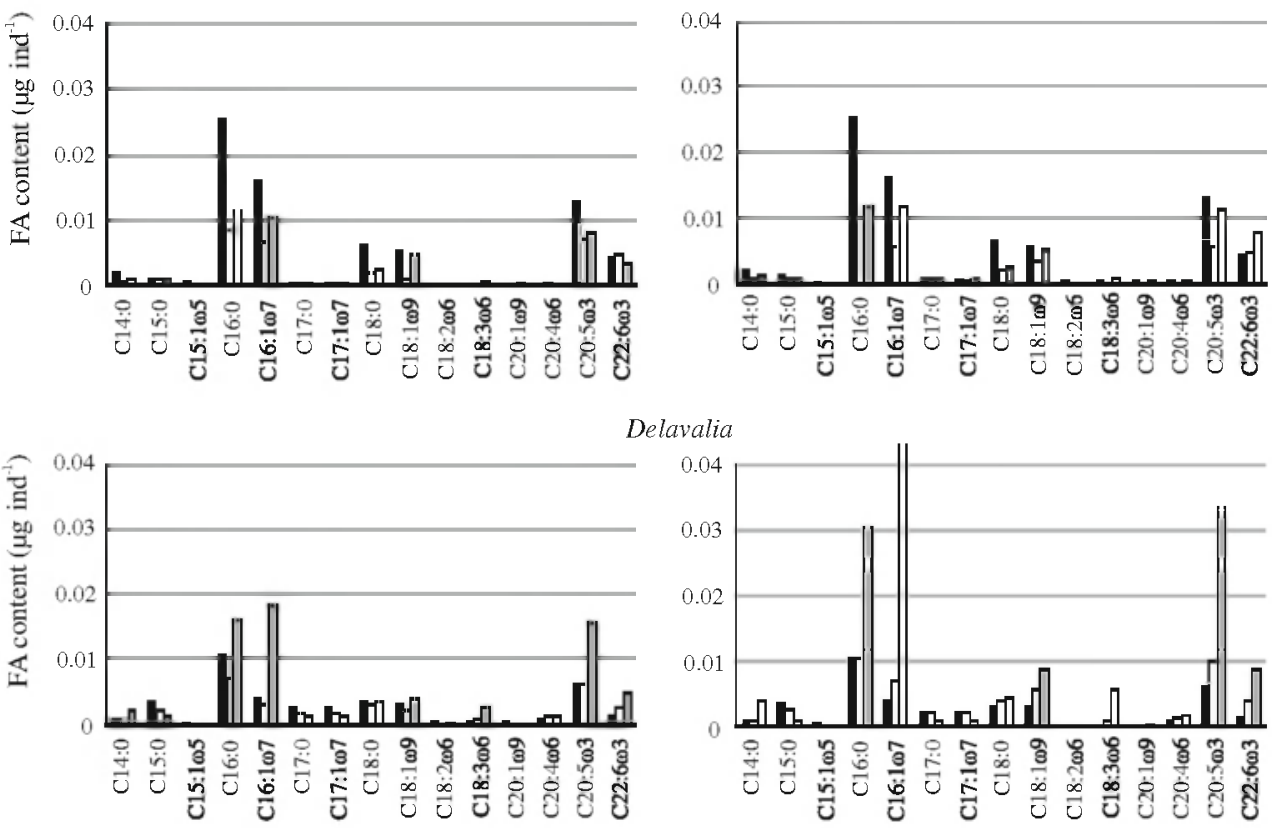

Delavalia

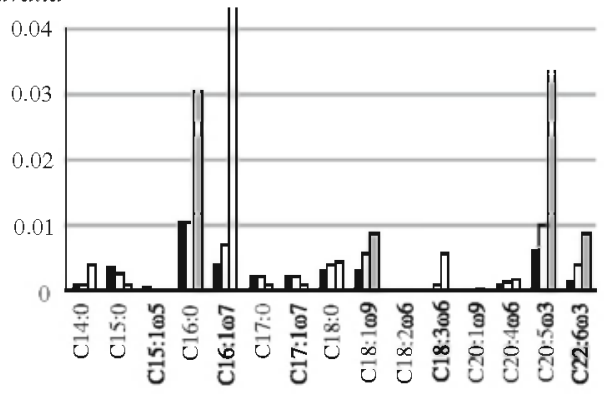

$\mathrm{T}_{0} \mathrm{DB} \mathrm{BD}$

Fig. 5 Fatty acid composition ( $\mu \mathrm{g}$ ind $^{-1}$ ) of the copepods Platychelipus, Nannopus and Delavalia after grazing during 4 days $\left(\mathrm{T}_{4}\right)$ and 9 days $\left(T_{9}\right)$ on bacteria without an additional substrate present

less preferred sediments (habitat selection) such as muffled sediment though it probably still depended on the sediment for food uptake (C. Cnudde, pers obs). Platychelipus does not emerge from the sediment into the water. It is clearly well adapted to live in or on top of the sediment. In spite of its high survival into the muffled sediment, Platychelipus showed only a marginal bacterial uptake. Rieper (1978) reported slightly higher rates of bacterivory for Tisbe holothuriae and Paramphiascella vararensis when bacteria were mixed with beach-sand grains. For muddy sediments, as in our study, bacterivory was not stimulated by the presence of grains. The negative effects of sediment in our study could be the result of the sediment pretreatment. Muffling altered grain size as the muffled sediment had a median grain size of $45 \mu \mathrm{m}$ and a $62 \%$ mud fraction. compared with natural sediment from the copepod habitat with a median grain size $126 \mu \mathrm{m}$ and a mud fraction of (treatment B) and with a diatom substrate (treatment BD), compared with fatty acid profiles of copepods before grazing $\left(T_{0}\right)$

$30 \%$. The presence of a higher fraction of very fine sediment particles and their looser texture and structure may have interfered with normal feeding, for instance by clogging the feeding apparatus or by accumulation inside the mouth cavity or intestine. This was also suggested as an explanation for the observation that fine sediment clearly interfered with grazing of copepods (Paramphiascella fulvofasciata, Nitocra spinipes) on diatoms (De Troch et al. 2006b).

On the other hand, the increased FA content of Platychelipus in the BDS versus BD treatment suggests that the presence of sediment stimulated diatom assimilation by Platychelipus. Hence, unlike in Microarthridion, the lack of bacterial uptake by Platychelipus in the sediment treatments is unlikely to have resulted from a negative impact of the sediment on copepod feeding activity, but rather indicates that this species is incapable of efficiently 
accessing bacteria that are mixed with sediment. Cultured bacteria are effective short-term sediment stabilizers through production of exopolymer secretions (EPS) during grain adhesion, implying that bacterial attachment to sediment grains likely occurred during the experiment. The observation that Platychelipus hardly assimilated bacterial carbon in our sediment treatments suggests that this species does not scrape off bacteria from sediment grains nor exhibits unselective ingestion of sediment particles and its associated microorganisms, even though exploitation of particle-bound bacteria through substrate ingestion and stripping in the gut has been reported for Leptocaris brevicornis (Decho and Castenholz 1986). Judging from the FA profiles, Platychelipus did, however, efficiently graze on diatoms and probably co-ingested and co-assimilated bacteria with diatoms, resulting in a higher uptake of bacterial carbon in the BD treatment. Co-ingestion of bacteria while feeding on diatoms was found in three out of four copepod species tested here, that is, Platychelipus, Delavalia and Microarthridion, while in the fourth species, Nannopus, no apparent diatom grazing occurred even after prolonged incubation ( 9 days). This study indicates that for diatom-feeding harpacticoids, bacterial grazing is strongly dependent on diatom ingestion as a significant part of bacterial grazing is realized through co-ingestion of bacteria with diatoms. Diatoms are thus expected to be the primary food source, even though the reverse, that is, assimilation of bacteria and egestion of undigested diatom cells, has also been reported for Leptocaris brevicornis (Decho and Castenholz 1986).

For Platychelipus, the effect of diatom presence on the bacterial uptake rate was incoherent between the two experiments, in spite of copepod total FA content demonstrating active feeding on diatoms in both setups. Specific and biomass-specific uptakes were similar for the B treatment in both experiments, but were much lower in the BD treatment of the first experiment compared with the second. We have no clear explanation for this discrepancy.

Microphytobenthos, mainly diatoms, are known as a primary food source for intertidal saltmarsh meiofauna (Pinckney et al. 2003; Galvan et al. 2008). Few field studies have addressed seasonal food availability in relation to population dynamics and feeding ecology of individual harpacticoid species or genera. Microarthridion littorale and Nannopus palustris are known as diatom feeders (Santos et al. 1995). This is supported by the natural $\delta^{13} \mathrm{C}$ of both species in the current study (ca. $-16 \%$ ), which is very close to that of microphytobenthos at the Paulina field site (Moens et al. 2002, 2005a), and by the high values of FA C $16: 1 \omega 7$ and $\mathrm{C} 20: 5 \omega 3$, known as characteristic for Bacillariophyceae (Kelly and Scheibling 2012). The lack of FA accumulation by Nannopus in the BD treatment may point at feeding selectivity, with the diatoms used in our experiment perhaps being an unsuitable source for this species. Data on the importance of microphytobenthos for Platychelipus littoralis and Delavalia palustris and their general trophic ecology are, however, lacking. The abundances of Bacillariophyceae FA in these species varied considerably. Their natural $\delta^{13} \mathrm{C}$ signals (Platychelipus ca. $-15 \%$ and Delavalia ca. $-17 \%$ ) were, however, very close to these of Microarthridion and Nannopus and within the range of microphytobenthos values known for the study site (Moens et al. 2002, 2005a). The somewhat more depleted $\delta^{13} \mathrm{C}$ values of Delavalia nevertheless suggest some contribution of settled phytoplankton detritus (Moens et al. 2002). Moreover, this is the only species out of the four species tested that showed high abundances of oddbranched bacterial biomarker FA (C15:0, C17:0, C17:1 17$)$. Delavalia is a typical tube-builder and tubedweller (Nehring 1993) and covers the inner tube wall with a mucoid substance secreted by cuticular glands (WilliamsHowze and Fleeger 1987). Mucus secretion and the presence of secretory mucus glands have been reported for only a few harpacticoid copepods: Heteropsyllus nunni (Coull and Grant 1981), Pseudostenhelia sp. (Williams-Howze and Fleeger 1987) and Diarthrodes nobilis (Hicks and Grahame 1979). The former two have a largely sessile life, respectively involving dormancy and tube-building, and mucus functions in copepod 'housing' (dormancy capsule, tube) but may also be used for bacterial gardening, as also observed for nematodes (Riemann and Helmke 2002; Moens et al. 2005b). The latter copepod species uses a mucus capsule as temporary protective shield while feeding on algae. Nevertheless, mucus may also be involved in feeding, since some juvenile Diarthrodes were found to survive and develop inside the capsules, obtaining their energy from the bacteria-rich mucus and entrapped organic debris (Hicks and Grahame 1979). Delavalia is not permanently residing in its tubes, and after some time in experimental settings, we could observe that this species 'sticks' to the bottom of Petri dishes. This might suggest the production of adhesive mucus (C. Cnudde pers observ). Since our data demonstrate a copepod-bacteria trophic interaction for Delavalia only, we hypothesize that Delavalia may apply such a microbial gardening strategy, the importance of which is, however, not as strong as for the above-mentioned sessile copepods.

Direct transfer of bacterial FA to harpacticoids and other insights into FA dynamics

For three out of four harpacticoid species, a marked impoverishment in total FA content was observed when offered bacteria as the only food, but not so for Delavalia. In contrast, all species except Nannopus accumulated FA on a mixed diet of bacteria and diatoms. 
FA loss in copepods in the bacteria treatment is mainly noticeable in the highly abundant FA such as the C16 FA and PUFA. C16 FA, which were among the main FA in the bacterial inoculum, were not incorporated, except by $D e$ lavalia. Delavalia was the only species that acquired dietary FA from an exclusively bacterial diet (final FA content: $121 \%$ ). This species mainly incorporated the most abundant FA in the bacterial inoculum: $\mathrm{Cl} 6: 1 \omega) 7$ and C18:1 (1)9. Little or no incorporation of less abundant FA

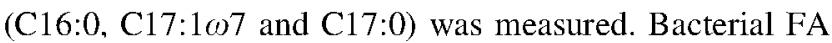
contribute more than $15 \%$ to Delavalia FA, while $<5 \%$ for Nannopus and Platychelipus. Studies on the lipid dynamics in marine copepods are mostly focusing on calanoid copepods, particularly on their even-chain FA, and do not report bacterial FA (Pasternak et al. 2009). One of the few studies dealing with the natural FA content of harpacticoids is Leduc et al. (2009), in which the proportion of bacterial FA in 'bulk' harpacticoids, mainly consisting of Parastenhelia megarostrum, was $<5 \%$. This is in agreement with the bacteria FA found here in Nannopus and Platychelipus but considerably less than in Delavalia. In Heteropsyllus nunni, the total of $\mathrm{C} 15: 0$ and $\mathrm{C} 17: 0$ comprised almost $10 \%$ of FA content (Williams and Biesiot 2004). Here, we demonstrate that bacterial FA can be directly transferred to harpacticoid copepods. Further, Delavalia increased its PUFA content on this bacterial diet, as levels of EPA and DHA were elevated in the B treatment already after 4 days. PUFA were absent from the bacterial diet, and we can provide no other explanation than de novo production of these PUFA by Delavalia (bioconversion). These are vital fatty acids, required for somatic growth and membrane functioning, making copepods a highly nutritional prey for juvenile fishes (Rajkumar and Vasagam 2006). Since higher trophic levels depend on dietary omega-3 PUFA, tracing these long-chain FA provides valuable information about how carbon is channeled through marine food webs (Brett and Muller-Navarra 1997).

In the treatment with diatoms. Platychelipus and Delavalia incorporated a broad spectrum of FA. The elevated levels of the diatom-specific PUFA and to a lesser extent of C18:3 $\omega 6$ are indicative of the nutritional value of diatoms for these two copepods. No incorporation of the bacteriaspecific $\mathrm{C} 17$ FA was detected, and increases in FA such as $\mathrm{C} 14: 0$ and $\mathrm{C} 18: 1(1) 9$ could originate from diatoms as well as from bacteria.

Overall, Delavalia was able to derive FA from both diatoms and bacteria, Platychelipus and Microarthridion only from diatoms, and Nannopus did not accumulate FA from neither diatoms nor bacteria. In all, these results suggest that bacteria represent a low-quality food and at best an additional food source for the harpacticoid copepods used here. This is in line with the main findings of
Souza-Santos et al. (1999) as they concluded that diatoms were the main dietary component and bacteria are a source of vitamin. Only in Delavalia, bacterivory was accompanied by clear assimilation of dietary FA. Therefore, proper assessment of the importance of bacterivory for harpacticoid copepods should focus not only on uptake and assimilation, but also on incorporation of FA by the consumers. It is important to note that consumer FA profiles do not necessarily reflect those of their food source as important modifications may take place. It is therefore essential to consider the possibility of bioconversion [e.g., elongations of short-chain FA; De Troch et al. (2012)] rather than merely focusing on the direct transfer of bacteria-specific FA to grazers.

\section{Conclusion}

The four sediment-dwelling intertidal harpacticoid copepods consumed bacteria at low rates, partly due to passive ingestion and partly by co-ingestion with benthic diatoms, but not by co-ingestion with sediment. This study demonstrates that bacterial FA can be directly accumulated by only some harpacticoids (Delavalia), whereas diatom FA were assimilated by three species. Delavalia also produced polyunsaturated FA from a bacterial diet lacking these FA. Generally, however, our results indicate that bacteria represent a minor and low-quality food for intertidal harpacticoid copepods.

Acknowledgments The first author acknowledges a PhD grant of IWT (Institute for the Promotion of Innovation through Science and Technology in Flanders). MDT is a postdoctoral researcher financed by the Special Research Fund at the Ghent University (GOA project 01GA1911 W). Financial support was obtained from the Flemish Science Foundation through project 3G019209 W and from the research council of Ghent University through project BOF09/24 J/148. Special thanks go to Ir. Dirk Van Gansbeke (Marine Biology, UGent) for analyzing the fatty acids and Annick Vankenhove for her help with sorting the copepods. The authors thank two anonymous reviewers for their constructive remarks that contributed to the improvement of the manuscript.

\section{References}

Abdulkadir S, Tsuchiya M (2008) One-step method for quantitative and qualitative analysis of fatty acids in marine animal samples. J Exp Mar Biol Ecol 354:1-8

Azam F, Fenchel T, Field JG, Gray JS, Meyerreil LA, Thingstad F (1983) The ecological role of water-column microbes in the sea Mar Ecol Prog Ser 10:257-263

Berggreen U, Hansen B, Kiørboe T (1988) Food size spectra, ingestion and growth of the copepod Acartia tonsa during development-implications for determination of copepod production. Mar Biol 99:341-352 
Boecklen WJ, Yarnes CT, Cook BA, James AC (2011) On the use of stable isotopes in trophic ecology. Annu Rev Ecol Syst 42:411440

Brett MT, Muller-Navarra DC (1997) The role of highly unsaturated fatty acids in aquatic food web processes. Freshw Biol 38:483499

Carman KR (1990) Mechanisms of uptake of radioactive labels by meiobenthic copepods during grazing experiments. Mar Ecol Prog Ser 68:71-83

Carman KR, Thistle D (1985) Microbial food partitioning by 3 species of benthic copepods. Mar Biol 88:143-148

Chen M, Lui H, Chen B (2012) Effects of dietary essential fatty acids on reproduction rates of a subtropical calanoid copepod, Acartia erythraea. Mar Ecol Prog Ser 455:95-110

Chepurnov VA, Mann DG, Vyverman W, Sabbe K, Danielidis DB (2002) Sexual reproduction, mating system, and protoplast dynamics of Seminavis (Bacillariophyta). J Phycol 38:1004-1019

Cnudde C, Willems A, Van Hoorde K, Vyverman W, Moens T, De Troch M (2011) Effect of food preservation on the grazing behavior and on the gut flora of the harpacticoid copepod Paramphiascella fulvofasciata. J Exp Mar Biol Ecol 407:63-69

Coull BC, Grant J (1981) Encystment discovered in a marine copepod. Science 212:342-344

Dahms H-U, Harder T, Qian P-Y (2007) Selective attraction and reproductive performance of a harpacticoid copepod in a response to biofilms. J Exp Mar Biol Ecol 341:228-238

De Troch M, Chepurnov V, Gheerardyn H, Vanreusel A, Olafsson E (2006a) Is diatom size selection by harpacticoid copepods related to grazer body size? J Exp Mar Biol Ecol 332:1-11

De Troch M, Houthoofd L, Chepurnov VA, Vanreusel A (2006b) Does sediment grain size affect diatom grazing by harpacticoid copepods? Mar Environ Res 61:265-277

De Troch M, Chepurnov VA, Vincx M, Olafsson E (2008) The effect of Fucus vesiculosus on the grazing of harpacticoid copepods on diatom biofilms. J Sea Res 60:139-143

De Troch M, Cnudde C, Vyverman W, Vanreusel A (2009) Increased production of faecal pellets by the benthic harpacticoid Paramphiascella fulvofasciata: importance of the food source. Mar Biol 156:469-477

De Troch M, Cnudde C, Willems A, Moens T, Vanreusel A (2010) Bacterial colonization on fecal pellets of harpacticoid copepods and on their diatom food. Microb Ecol 60:581-591

De Troch M, Boeckx P, Cnudde C, Van Gansbeke D, Vanreusel A, Vincx M, Caramujo MJ (2012) Bioconversion of fatty acids at the basis of marine food webs: insights from a compoundspecific stable isotope analysis. Mar Ecol Prog Ser 465:53-67

Decho AW (1986) Water-cover influences on diatom ingestion rates by meiobenthic copepods. Mar Ecol Prog Ser 33:139-146

Decho AW, Castenholz RW (1986) Spatial patterns and feeding of meiobenthic harpacticoid copepods in relation to resident microbial-flora. Hydrobiologia 131:87-96

Desvilettes C, Bourdier G, Breton JC (1997) On the occurrence of a possible bioconversion of linolenic acid into docosahexaenoic acid by the copepod Eucyclops serrulatus fed on microalgae. J Plankton Res 19:273-278

Eder K (1995) Gas-chromatographic analysis of fatty-acid methylesters. J Chromatogr B-Biomed Appl 671:113-131

Epstein SS (1997) Microbial food webs in marine sediments.I. Trophic interactions and grazing rates in two tidal flat communities. Microb Ecol 34:188-198

Epstein SS, Shiaris MP (1992) Rates of microbenthic and meiobenthic bacterivory in a temperate muddy tidal flat community. Appl Environ Microbiol 58:2426-2431

Fujiwara M, Highsmith RC (1997) Harpacticoid copepods: potential link between inbound adult salmon and outbound juvenile salmon. Mar Ecol Prog Ser 158:205-216
Galvan K, Fleeger JW, Fry B (2008) Stable isotope addition reveals dietary importance of phytoplankton and microphytobenthos to saltmarsh infauna. Mar Ecol Prog Ser 359:37-49

Griebler C, Mindl B, Slezak D (2001) Combining DAPI and SYBR Green II for the enumeration of total bacterial numbers in aquatic sediments. Int Rev Hydrobiol 86:453-465

Guckert JB, Antworth CP, Nichols PD, White DC (1985) Phospholipid, ester-linked fatty-acid profiles as reproducible assays for changes in prokaryotic community structure of estuarine sediments. FEMS Microbiol Ecol 31:147-158

Guillard RL (1975) Culture of phytoplankton for feeding marine invertebrates. In: Smith WL, Chandley MH (eds) Culture of marine invertebrate animals. Plenum Press, New York, pp 26-60

Hicks GRF (1977) Observations on substrate preference of marine phytal harpacticoids (Copepoda). Hydrobiologia 56:7-9

Hicks GFR, Coull BC (1983) The ecology of marine meiobenthic harpacticoid copepods. Oceanogr Mar Biol Annu Rev 21:67-175

Hicks GRF, Grahame J (1979) Mucus production and its role in the feeding-behavior of Diarthrodes nobilis (Copepoda, Harpacticoida). J Mar Biol Assoc U K 59:321-330

Hondeveld BJM, Bak RPM, Vanduyl FC (1992) Bacterivory by heterotrophic nanoflagellates in marine sediments measured by uptake of fluorescently labeled bacteria. Mar Ecol Prog Ser 89:63-71

Huys R, Gee JM, Moore GC, Hamond R (1996) Marine and brackish water harpacticoid copepods. Part 1 Keys and notes for identification of the species. In: Barnes RSK and Crothers JH (eds.) Synopses of the Britain Fauna (New Series) no. 51. Field Studies Council, Shrewsbury

Kelly JR, Scheibling RE (2012) Fatty acids as dietary tracers in benthic food webs. Mar Ecol Prog Ser 446:1-22

Kemp PF (1988) Bacterivory by benthic ciliates-significance as a carbon source and impact on sediment bacteria. Mar Ecol Prog Ser 49:163-169

Lang K (1948) Monographie der Harpacticiden. Håkan Ohlssons Boktryckeri, Lund

Leduc D, Probert PK, Duncan A (2009) A multi-method approach for identifying meiofaunal trophic connections. Mar Ecol Prog Ser 383:95-111

Leroy F, Riera P, Jeanthon C, Edmond F, Leroux C, Comtet T (2012) Importance of bacterivory and preferential selection toward diatoms in larvae of Crepidula fornicata (L.) assessed by a dual stable isotope $\left({ }^{13} \mathrm{C},{ }^{15} \mathrm{~N}\right)$ labeling approach. J Sea Res 70:23-31

Ling SC, Alldredge AL (2003) Does the marine copepod Calanus pacificus consume transparent exopolymer particles (TEP)? J Plankton Res 25:507-515

Marcotte BM (1977) An introduction to the architecture and kinematics of harpacticoid (Copepoda) feeding: Tisbe furcata (Baird, 1837). Mikrofauna des Meeresbodens 61:183-196

McCall JN (1992) Source of harpacticoid copepods in the diet of juvenile starry flounder. Mar Ecol Prog Ser 86:41-50

Michels J, Schnack-Schiel SB (2005) Feeding in dominant antarctic copepods-does the morphology of the mandibular gnathobases relate to diet? Mar Biol 146:483-495

Middelburg JJ, Barranguet C, Boschker HTS, Herman PMJ, Moens T, Heip CHR (2000) The fate of intertidal microphytobenthos carbon: an in situ ${ }^{13} \mathrm{C}$-labeling study. Limnol Oceanogr 45:1224-1234

Moens T, Verbeeck L, de Maeyer A, Swings J, Vinex M (1999a) Selective attraction of marine bacterivorous nematodes to their bacterial food. Mar Ecol Prog Ser 176:165-178

Moens T, Verbeeck L, Vincx M (1999b) Preservation and incubation time-induced bias in tracer-aided grazing studies on meiofauna. Mar Biol 133:69-77

Moens T, Luyten C, Middelburg JJ, Herman PMJ, Vincx M (2002) Tracing organic matter sources of estuarine tidal flat nematodes with stable carbon isotopes. Mar Ecol Prog Ser 234:127-137 
Moens T, Bouillon S, Gallucci F (2005a) Dual stable isotope abundances unravel trophic position of estuarine nematodes. J Mar Biol Assoc U K 85:1401-1407

Moens T, dos Santos GAP, Thompson F, Swings J, Fonseca-Genevois V, Vincx M, De Mesel I (2005b) Do nematode mucus secretions affect bacterial growth? Aquat Microb Ecol 40:77-83

Montagna PA, Blanchard GF, Dinet A (1995) Effect of production and biomass of intertidal microphytobenthos on meiofaunal grazing rates. J Exp Mar Biol Ecol 185:149-165

Nehring S (1993) Tube-dwelling meiofauna in marine-sediments. Int Rev Gesamten Hydrobiol 78:521-534

Pascal PY, Dupuy C, Richard P, Mallet C, Armynot du Chatelet E, Niquil N (2009) Seasonal variation in consumption of benthic bacteria by meio- and macrofauna in an intertidal mudflat. Limnol Oceanogr 54:1048-1059

Pasternak A, Hagen W, Kattner G, Michels J, Graeve M, SchnackSchiel SB (2009) Lipid dynamics and feeding of dominant antarctic calanoid copepods in the eastern Weddell Sea in December. Polar Biol 32:1597-1606

Perlmutter DG, Meyer JL (1991) The impact of a stream-dwelling harpacticoid copepod upon detritally associated bacteria. Ecology $72: 2170-2180$

Pinckney JL, Carman KR, Lumsden SE, Hymel SN (2003) Microalgal-meiofaunal trophic relationships in muddy intertidal estuarine sediments. Aquat Microb Ecol 31:99-108

Porter KG, Feig YS (1980) The use of DAPI for identifying and counting aquatic microflora. Limnol Oceanogr 25:943-948

R Development Core Team (2009) R: a language and environment for statistical computing. R Foundation for Statistical Computing, Vienna, Austria. ISBN 3-900051-07-0, URL http://www.Rproject.org

Rajkumar M, Vasagam KPK (2006) Suitability of the copepod, Acartia clausi as a live feed for seabass larvae (Lates calcarifer Bloch):compared to traditional live-food organisms with special emphasis on the nutritional value. Aquaculture 261:649-658

Riemann F, Helmke E (2002) Symbiotic relations of sedimentagglutinating nematodes and bacteria in detrital habitats: the enzyme-sharing concept. Mar Ecol 23:93-113

Rieper M (1978) Bacteria as food for marine harpacticoid copepods. Mar Biol 45:337-345

Rieper M (1982) Feeding preferences of marine harpacticoid copepods for various species of bacteria. Mar Ecol Prog Ser 7:303-307

Roff JC, Turner JT, Webber MK, Hopcroft RR (1995) Bacterivory by tropical copepod nauplii-extent and possible significance. Aquat Microb Ecol 9:165-175
Santos PJP, Castel J, Souza-Santos LP (1995) Microphytobenthic patches and their influence on meiofaunal distribution. Cah Biol Mar 36:133-139

Santos PJP, Souza-Santos LP, Castel J (2003) Population dynamics of Nannopus palustris (Copepoda, Harpacticoida) in the oligomesohaline area of the Gironde estuary (France). Cah Biol Mar 44:329-338

Sapp M, Gerdts G, Wellinger M, Wichels A (2008) Consuming algal products: trophic interactions of bacteria and a diatom species determined by RNA stable isotope probing. Helgol Mar Res 62:283-287

Schmidt JL, Deming JW, Jumars PA, Keil RG (1998) Constancy of bacterial abundance in surficial marine sediments. Limnol Oceanogr 43:976-982

Seifried S, Durbaum J (2000) First clear case of carnivory in marine Copepoda Harpacticoida. J Nat Hist 34:1595-1618

Souza-Santos LP, Castel J, Santos PJP (1996) The role of phototrophic sulfur bacteria as food for meiobenthic harpacticoid copepods inhabiting eutrophic coastal lagoons. Hydrobiologia 329:79-89

Souza-Santos LP, Santos PJP, Castel J (1999) Development and population dynamics of Amonardia normani Brady reared on axenic and non-axenic diatoms. J Exp Mar Biol Ecol 235: $167-182$

Tang KW, Hutalle KML, Grossart H-P (2006) Microbial abundance, composition and enzymatic activity during decomposition of copepod carcasses. Aquat Microb Ecol 45:219-227

Turner JT, Tester PA (1992) Zooplankton feeding ecology-bacterivory by metazoan microzooplankton. J Exp Mar Biol Ecol 160:149-167

van Oevelen D, Middelburg JJ, Soetaert K, Moodley L (2006) The fate of bacterial carbon in sediments: modeling an in situ isotope tracer experiment. Limnol Oceanogr 51:1302-1314

Vandenberghe W, Bergmans M (1981) Differential food preferences in 3 co-occurring species of Tisbe (Copepoda, Harpacticoida). Mar Ecol Prog Ser 4:213-219

Veloza AJ, Fu-Lin E, Tang KW (2006) Trophic modification of essential fatty acids by heterotrophic protists and its effect on the fatty acid composition of the copepod Acartia tonsa. Mar Biol 148:779-788

Williams JL, Biesiot PM (2004) Lipids and fatty acids of the benthic marine harpacticoid copepod Heteropsyllus nunni Coull during diapause: a contrast to pelagic copepods. Mar Biol 144:335-344

Williams-Howze J, Fleeger JW (1987) Pore pattern: a possible indicator of tube-building in Stenhelia and Pseudostenhelia (Copepoda: Harpacticoida). J Crustac Biol 7:148-157 